DOI 10.37882/2500-3682.2020.05.01

\title{
ЭВОЛЮЦИЯ СОВРЕМЕННЫХ КИТАЙСКИХ РИТУАЛОВ И ОБЫЧАЕВ РОЖДЕНИЯ
}

\section{THE EVOLUTION OF MODERN CHINESE RITUALS AND CUSTOMS OF BIRTH} Wang Dan

Summary: The ritual of life is an important part of the state and folk Chinese culture. The subject of analysis of this work was the evolution of Chinese rituals and customs of birth. The rituals and customs of birth according to chronology consist of three main stages: Prayer custom before the birth of a child, Customs during pregnancy and the Ritual after the birth of a child. The most important third stage includes four main components: the ritual of washing the newborn baby (on the 3rd day), the ritual of the one month old, the ritual of the hundredth day from the day of the birth of the child, the ritual of the one year old. For more than two thousand years, the rituals and customs of birth have undergone a long tradition, are constantly enriched and improved, some have been preserved to this day, some have been lost. Some retained their former form, but changed the content; others created new rituals on the same topic. Over time, the religious appearance of the ritual of life gradually faded and reduced to simplicity, a tendency to secularization arose. This result of the secularization of life etiquette inevitably merges into modern social interaction and gradually turns into an integral part of social etiquette.

Keywords: China, traditional culture, ritual, life rituals, The rituals and customs of birth, evolution of rituals and customs, secularization of birth rituals.

\author{
Ван Дань \\ Дальневосточный федеральный университет \\ (Владивосток) \\ wangdan1990112@163.com
}

Аннотация: Ритуалы, сопровождающие бытовую жизнь человека от рождения до смерти (ритуалы жизни), являются важной частью государственной и народной китайской культуры. Особое место в ритуалах жизни занимают ритуалы и обычаи рождения. Целью исследования стало изучение эволюции китайских ритуалов и обычаев рождения. Установлено, что ритуалы и обычаи рождения включают три основных этапа: молитвенный обычай до рождения ребенка, обычаи в периоде беременности и ритуал после рождения ребенка. Самый важный третий этап включает в себя четыре основных компонента: ритуал омовения новорождённого младенца (на 3-й день), ритуал исполнившегося месяца, ритуал сотого дня со дня рождения ребенка, ритуал исполнившегося года. Традиции ритуалов и обычаев рождения на протяжении более двух тысяч лет постоянно обогащались и совершенствовались. Часть из них сохранилась и по сей день, часть была утрачена, некоторые сохранили прежнюю форму, но изменили содержание; кроме того, фиксируются и новые ритуалы рождения. Со временем религиозный облик ритуала рождения постепенно менялся в сторону упрощения и секуляризации.

Ключевые слова: Китай, традиционная культура, ритуал, ритуалы жизни, ритуалы и обычаи рождения, эволюция ритуалов и обычаев, секуляризация ритуалов рождения.
$\mathrm{O}$ дной из древних традиций Китая является сопровождение разных этапов жизни человека протяжении всей его жизни, от рождения до смерти, специальными обрядами и ритуалами, напоминающими об этих ключевых событиях. Через определенные ритуалы передаются глубокие смыслы человеческой жизни и культурные коннотации разных ее этапов. В целом, эти обряды, проводимые в разные возрастные периоды, в Китае называются «生命礼仪» («Шэн Мин Ли И»), что в переводе на русский язык означает «ритуалы жизни». Понятие «ритуалы жизни», в мировой культуре также известны как «ритуалы перехода» (ритуалы, сопровождающие изменение социального положения, статуса; напр., обряд бракосочетания) [1, с. 70]. Традиционные ритуалы, которые проходят через жизнь человека, включают в себя ритуалы: рождения, взросления, свадьбы, похорон и т.д.

Рождение и воспитание детей является важным элементом жизни человеческого общества, в результате чего крепнет институт семьи, а народы процветают. Таким образом, ритуал рождения, который знаменует начало первого этапа жизни, очень важен. Когда ребенок пришел в мир с криком, смысл его существования быть просто живым существом. Ритуал рождения символизирует начало его собственного пути к взрослой жизни.

Несмотря на неугасающий интерес к культуре Китая в российской науке, многие ее аспекты до сих пор остаются до конца не освещенными исследователями. В частности, изучение специализированной литературы показало явную недостаточность российских исследований о китайских ритуалах и обычаях рождения. Несмотря на то, что Китае эти вопросы широко освещаются, автором не было выявлено сравнительного анализа этих форм ритуалов между традицией и современностью в китайских источниках.

В данной статье, наряду с описанием ритуалов и обычаем рождения Китая, подробно анализируется их эво- 
люция в современной китайской культуре.

Ритуал рождения обычно представляется как серия ритуалов после того, как ребенок придет в мир. На самом деле, ритуал рождения в Китае начинается не с момента рождения человека, а с момента зачатия. Можно сказать, что ритуал рождения начинается уже тогда, когда плод еще не сформировался в матери. Традиционно ритуал рождения может содержать в основном три этапа: молитвенный обычай до рождения ребенка; обычай в периоде беременности; ритуал после рождения ребенка.

\section{Молитвенный обычай $\Delta$ рожАения ребенка}

Поскольку традиционный обычай молитв о ниспослании ребенка в настоящее время ограничен научными и медицинскими технологиями, он имеет суеверный оттенок. Однако, в традиционной культуре все надежды на продление рода возлагаются на сакральные предметы и богов.

В древние времена на свадьбах на кровати новобрачных ставили китайские финики, потому что «丰» («Цзао») - «Финик» - это омоним «早» («Цзао») - «Рано», что означает желать скорого рождения ребёнка. Красоднев (лилейник) рыжий, известный как «宜男草» («И Нань Цао»), также является особым предметом и традиционно понимается со следующим значением: «Беременные женщины носят его, а затем рождают мальчика» $[2$, с. 1$]$.

С другой стороны, просить сына у богов, ответственных за деторождение, также было обычным способом молиться в древние времена. Например, в сборнике рассказов конца династии Мин «初刻拍案惊奇》(《Поразительное. Первая часть»), написано : «离山一里之外, 有个 大姓仇氏。夫妻两个, 年登四十。极是好善, 并无子嗣。 乃舍钱刻一慈悲大士像, 供礼于家……如是三年, 其妻果 然有了胎孕, 十月期满, 晚间生下一个女孩。夫妻两个, 欢 喜无限, 取名夜珠》, что означает следующее: «Есть муж и жена по фамилии Цю, добродушные, уже более сорока лет, нет детей, поэтому потратили деньги на скульптуру богини Гуань-инь, дарящая сыновей, чтобы молиться в доме, три года спустя, жена действительно беременна, родила дочь, назвала ночную жемчужину»[3, с. 174].

Несмотря на то, что современные обычаи молитвы о ниспослании ребенка постепенно отделяются от влияния суеверных идей из-за эпохи технического прогресса, многие из них все равно в значительной степени зависят от укоренившихся традиционных идей. В современном обществе, как правило, в ночь перед свадьбой, в новом доме должны быть один или два мальчика, которые спят на новой кровати для новобрачных. Дети, как правило, относятся к отцовской линии, предпочтение отдается умным мальчикам. На следующее утро мальчики должны были завтракать в постели, они просят палочки для еды и говорят хором «筷子» («Куай Цзы») - палочки для еды, это является омонимом «快子» («Куай Цзы») и символизируют быстрое рождение ребенка. На кровати и во всех ящиках нового дома также должны быть размещены китайские финики и монеты, что также направлено на скорое рождение ребенка [4, с. 79].

В современном Китае, после вступления в брак, благодаря развитию здравоохранения и повышению познавательной способности людей, китайцы более охотно верят в возможности медицины, даже при длительном бесплодии в браке, а также готовы идти в больницу для обследования и лечения. Таким образом, зависимость от древних, притягивающих удачу и благополучие лилейников и богов, значительно уменьшилась. Сравнение между традиционными и современными обычаями молитвы о ниспослании ребенка позволяет говорить о том, что современное общество Китая ориентировано на развитие науки и техники, способность человека к познанию. Благодаря постоянному повышению познавательной способности, современные люди предпочитают верить в науку и технику, а не традиционные символы.

\section{Обычаи в периоде беременности}

Традиционные обычаи в период беременности включают в себя такие аспекты, как пренатальное воспитание, поведение и питание и т.д. В летописи «Исторические записки» сказано: “太任有娠, 目不视恶色, 耳不听淫声, 口 不吐傲言》, что означает следующее: «Когда мать Чжоу Вэньван ${ }^{2}$ была беременна, ее глаза не видели плохого цвета, ее уши не слушали непристойных звуков, и рот не говорила заносчивых и невежливых слов» $[5$, с. 10]. Это означает, что беременные женщины должны быть в хорошем и оптимистическом настроении. Они также могут быть вдохновлены красивой внешней средой и хорошей духовной стимуляцией, чтобы плод получил здоровое и нормальное развитие. В древности также судили о рождении мальчиков и девочек по поведению беременных женщин во время беременности. Например, в соответствии с обычаями: мужчина - левая сторона, а женщина - правая сторона, наблюдая за беременной женщиной, когда она переступала через порог: если первый шаг левой ногой, то это предвещало рождение мальчика, а если первый шаг правой ногой - то девочку [3, с. 174].

Современные обычаи в период беременности, как и в древние времена, включают в себя питание, воспита-

«Исторические записки» - первый по времени создания комплексный труд по истории Древнего Китая, охватывает период от древности до династии Западная Хань. Автор трактата - историограф Сыма Цянь (145-86? гг. до н. э.).

2 Чжоу Вэньван (1152-1056 гг. до н.э.) - отец первого правителя китайской династии Чжоу; XII-XI вв. до н. э.) 
ние и поведение. В Китае наиболее заметным аспектом диеты во время беременности является то, что беременные женщины не могут есть холодную пищу, китайцы считают, что холодная пища из-за ее холода, приведет к трудным родам. Нельзя, также есть острую пищу - беременная женщина будет страдать от избытка внутреннего жара, что оказывает влияние на зрение плода. До сих пор на территории Китая есть традиция: тянет на кислое - к мальчику, тянет на острое - к девочке (традиционная китайская примета, относящаяся к беременности), то есть если беременные женщины любят есть кислый вкус во время беременности, плод может быть мальчик; а если острый вкус, вероятность рождения девушки больше [6, c. 64].

Современное пренатальное воспитание шире, чем древнее пренатальное воспитание: если традиционное пренатальное воспитание основано на поэзии, живописи, классической музыке и т. д., то современные китайцы, помимо сохранения традиционного содержания, из-за влияния западной культуры, более склонны использовать западную музыку и литературу. По сравнению с древностью, внешняя среда современного пренатального воспитания значительно превосходит древнюю.

Что касается поведения беременных женщин, то китайский ученый Юй Чи Цун Тай в своей статье пишет: « 孕妇忌参加婚礼、婚宴, 犯之, 主不顺当; 忌进各种庄 重、严肃的场所, 犯之, 主不吉利》 [7, с. 52]. Это означает, что беременные женщины не должны посещать свадьбы, похороны, новоселья, банкеты в честь получения повышения в чине и другие важные события, так как это плохо для развития плода. Старшее поколение уделяет этому большое внимание и нарушение табу подвергается жесткой критике. Сравнение с традицией и современностью показывает, что существуют большие различия в обычае беременности. Но также обнаруживается общая черта между ними, которая заключается в том, что до сих пор существуют различные суеверные обычаи.

\section{Ритуал после рожхения ребенка}

Ритуал после рождения ребенка - это важнейший из ритуалов рождения. В древности, рождение детей было радостным событием не только для отдельных лиц, но и для семей, родов и землячества. Таким образом, ритуал празднования рождения не ограничивается только семьей, но и имеет определенную социальную природу. Ритуалы после рождения ребенка до того, как ребенок достигнет возраста одного года, в разных местах примерно одинаковы и проводятся довольно часто. В основном они включают в себя четыре вида: ритуал омовения новорождённого младенца (на 3-й день), ритуал исполнившегося месяца, ритуал сотого дня со дня рождения ребенка, ритуал исполнившегося года.
«洗三礼» («Си Сань Ли») так называется «贺三朝» («Хэ Сань Чао») - это ритуал омовения новорождённого младенца на третий день рождения, означает, что новорожденный полностью вышел из состояния плода и с тех пор официально отправился в путешествие по жизни. В этот день хозяин попросил старушку, у которой была долгая и счастливая жизнь, провести церемонию омовения и произнести благословения, пока она купала ребенка. После церемонии хозяева приготовят праздничное угощение для друзей и семьи, обычно называется «三朝酒» («Сань Чао Цзю») [8, с. 45]. В древние времена «洗三礼» («Си Сань Ли») - (ритуал обмывать новорождённого младенца на третий день рождения) широко распространялся во всех слоях общества, от императорского двора до народных людей. Поэт династии Тан Ван Цзянь писал стихи «宫词» («дворцовая поэзия»), описывающий придворную жизнь: 《妃子院中初降诞, 内人争乞洗儿钱》, что означает следующее: «Императорская наложница родила ребенка, дворцовые служанки и евнухи попросили награду для омовения ребенка» [9, с. 513]. Таким образом, придворные придавали большое значение ритуалу омовения, так как этот день был большим праздником, поэтому хозяин готовил медные деньги для прислуги.

«洗三» («Си Сань») отличается от обычной бани, ритуал был очень сложным. Вода для омовения должна быть особой. В прозаическом произведении династии Сун « 东京梦华录》 (《Записи прекрасных снов о Восточной столице») говорится, что вода для омовения младенцев называется «香汤» («благовонная горячая вода»), в которой есть арахис, финики, каштаны, а также цветные линии, зеленый лук, чеснок и т.д. [10, с. 226]. Каждый элемент имеет символическое значение: арахис означает, что рождать ребенка, финик означает, что рано, каштан рождение сына, зеленый лук символизирует ум ребенка и т.д. Тот, кто купает ребенка, должен сказать: «洗洗头, 做王侯; 洗洗腰, 一辈倒比一辈高; 洗洗蛋, 做知县; 洗洗 沟, 做知州》 [11, с. 42] что означает: «вымыть голову, чтобы стать князем; вымыть поясницу, чтобы этот поколение лучше, чем предыдущее поколение; вымыть щёчки, чтобы стать начальник уезда; Вымыть межъягодичную складку, чтобы стать правитель округа». После омовения должен быть использован имбирь и листья полыни, чтобы чистить лоб и все важные суставы ребенка, говорят, что это сделает ребенка крепким в будущем. Наконец, новой тканью, смоченной чистой водой, вытирают десны ребенка с силой - если в это время ребенок рыдает во весь голос, это считается предзнаменованием большого счастья, родственники и друзья будут очень рады. После того, как семья будет использовать зеленый лук, чтобы мягко ударить ребенка три раза и сказать: «一打聪明, 二打伶俐, 三打明明白白» что означает: «ударить ребенка первый раз, значит он будет умным; ударить ребенка второй раз, значит он будет сообразительным; ударить ребенка третий раз, значит он будет понятливым» $[12$, с. 98]. После этого отец ребенка должен бросить зеленый 
лук на крышу, это предвещает, что желание сбудется. Затем родные и близкие поздравляют родителей малыша. В конце церемонии омовения медные деньги, арахис, яйца и другие предметы в ванне передаются гостям, которые хотели передать удачу с детьми своим друзьям и родственникам [12, с. 100].

В современном обществе ритуал омовения новорождённого младенца на 3-й день постепенно перестал использоваться. Причина в том, что в древности беременные женщины были дома, чтобы родить детей, поэтому омовение в основном проводилось повивальной бабкой, друзья и родственники приглашались домой для празднования этого события. С развитием современного медицины, матери и новорожденные младенцы находятся в больнице на обследовании в течение семи дней со дня родов. Врач выбирает время омовения в соответствии с физическим состоянием ребенка, одни дети могут принять ванну через несколько часов после рождения, а другие - через день или два. Процесс мытья ребенка также осуществляется профессиональным врачом, сильно отличается от ритуала омовения и не имеет особого символического значения. В то же время, поскольку больница является общественным местом, родственники и друзья предпочитают приносить поздравление после того, как мать выписана домой. Таким образом, ритуал омовения новорождённого младенца на третий день рождения постепенно исчез. Люди обращают больше внимания на ритуал исполнившегося месяца и ритуал исполнившегося года.

\section{Ритуал исполнившегося месяча}

«满月» («Мань Юе») - («Целый месяц») также известный как «弥月» («Ми Юе») - («ребёнку исполнился месяц») имеет большое значение как для младенцев, так и для матерей. Ребенку исполнился месяц, что достойно празднования. Роженица заканчивает послеродовой отдых, что также следует отметить. В обычаях династии Сун была организация торжественного банкета для родственников и друзей (по случаю первого купания новорождённого чтобы справлять месячины).

Писатель династии Сун Мэн Юаньлао (1103-1147) в своем произведении «东京梦华录》 (《Записи прекрасных снов о Восточной столице») описывает городской стиль и социальную жизнь в восточной столице династии Северная Сун - Кайфын, в пятом томе «育子» («рождение детей») рассказывается о том, как младенцы купались во время месячины, то есть ритуал исполнившегося месяца. В книге записано 《至满月则生色及朋绣线, 贵 富家金银犀玉为之, 并果子, 大展洗儿会。亲宾盛集, 煎香汤於盆中, 下果子彩钱葱蒜等, 用数丈彩绕之, 名 曰「围盆」。以钗子搅水, 谓之「搅盆」。观者各撒钱 於水中, 谓之「添盆」。盆中本子直立者, 妇人争取 食之, 以为生男之徵》 [10, с. 225], что означает: «Когда в день месячины, простые люди готовили нитки мулине, а богатые люди использовали золото, серебро, нефрит и другие ценные вещи, чтобы украшать ванну ребенка. В этот день хозяева пригласили друзей и семью собраться вместе, чтобы начать совершать омовение. Сначала наливали горячую воду в ванну, клали арахис, финики, каштаны, медные деньги, зеленый лук, чеснок и т. д. в воду. Использовали десятки метров цветных ниток вокруг ванны, мешали воду шпилькой для волос, друзья и родственники собрались вместе, клали медные деньги в воду. Когда финики в ванне стояли вертикально, то женщины боролись за первенство, чтобы их съесть, что помогало родить мальчика в будущем».

Когда ребёнку исполнился месяц, существовал ритуал бритья волос новорождённого. В книге «东京梦华 录» («Записи прекрасных снов о Восточной столице») записано «浴儿毕, 落胎发, 遍谢坐客》 [10, с. 225], что означает: «Побрить волосы новорождённого после обряда омовения, наконец, устроить банкет в честь благодарности гостей». В день исполнившегося месяца бреют волосы новорождённого так, чтобы защитить родничок: нельзя брить волосы полностью, оставляют около одного-двух цуней (мера длины, около 3,33 см) размера квадратных волос на переднем лбе ребенка, что называется оставлением пушка новорождённого, что символизирует надежду на будущие успехи ребенка.

Кроме того, в Китае есть старая поговорка о том, что тело и кожа ребенка являются подарками, подаренными родителями, в дополнение к необходимости оставить часть, чтобы выразить благодарность и почтение родителям, другая часть должна быть сохранена. В некоторых местах волосы новорождённого покрыты красной тканью, сшитой на подушке ребенка; в других местах втираются в круглые шарики, обернутые цветной нитью, что висят на изголовье кроватки, чтобы избегать злых влияний. В современном обществе популярно делать памятную кисть для письма из волос своего ребенка в качестве сувенира.

Существует также обычай «挪窝》 («перенести гнездо») для младенцев в день исполнившегося месяца. В книге «东京梦华录》 («Записи прекрасных снов о Восточной столице») записано 《抱牙儿入他人房, 谓之移窠》, что означает: «Назначенный человек увозит ребенка, чтобы ненадолго поселиться на другом месте, т. е. "переместить гнездо"» [10, с. 225]. Обычно бабушка или дядя приносят ребенка в свой дом, чтобы ребенок ненадолго пожил в другом месте. Цель состоит в том, чтобы позволить ребенку символически повидать на своём веку как можно больше, надеясь, что у дитя будет больше перспектив в будущем.

В наше время празднование исполнившегося месяца имеет два основных события: бритье волос новорождён- 
ного и банкет в честь новорожденного ребенка, которому исполнился месяц. В день исполнившегося месяца, родительская семья роженицы не только должна прийти поздравить, но и взять роженицу и ребенка домой, чтобы прожить несколько дней, ритуал называется «搬 满月» («Бань Мань Юе») или «叫满月» («Цзяо Мань Юе»). Кроме того, брови должны быть сбриты полностью, считается, что после этого у ребенка будет расти густые брови. Сбритые волосы не могут быть просто выброшены, большинство родителей делают памятную кисть для письма, сделанную из волос своего ребенка в качестве сувенира.

После бритья волос новорождённого, мама одевает его в новую одежду и устраивает банкет, как правило, в ресторане в честь новорожденного, чтобы угостить родных и близких. Родственники и друзья обычно должны принести одежду, обувь, шляпы, украшения и другие подарки для ребенка, чтобы праздновать. В Учжоу (городской округ в Гуанси-Чжуанском автономном районе КНР) банкет в честь новорожденного ребенка называют «姜宴》 («Цзян Янь») - банкетом имбири, потому что на банкете есть обычай есть кислый имбирь. В Шэньси существует особый обычай на празднование исполнившегося месяца, называемый «挂红» («Гуа Хун») - висящим красным. В этот день каждый человек может намазать лицо бабушки и дедушки ребенка красным цветом, в день исполнившегося месяца ребенка должны есть красные яйца и красное мясо, в спальне висят красные шторы, что означает радость, удачу, процветание.

\section{Ритуал сотого Аня со Аня рожАения ребенка}

В сотый день со дня рождения ребенка состоится «百 日礼» («Бай Жи Ли») ритуал сотого дня. Сто - это значительное число, имеющее полное, благополучное значение. В древние времена у ритуала сотого дня было много названий, таких как «百日卒» («Бай Жи Цзуй») - Стодневный юбилей, «百禄» («Бай Лу») - Моление на сотый день после рождения ребёнка, «百岁» («Бай Суй») - Сто лет, это желание ребенка долгих лет жизни. В древнем Китае из-за низкого медицинского уровня младенцы имели довольно высокую смертность в течение ста дней после рождения, и если ребенок может спокойно прожить 100 дней, намного больше вероятность того, что он вырастет. Так что этот день являлся праздником.

Для того, чтобы дети росли благополучными и здоровыми, родители придумывали различные способы спасения от несчастий. По всей стране существует обычай носить монисто в форме замка-амулета (составленное из собранных у родственников монет и надеваемое ребёнку на счастье), носить одежду для ребёнка, сшитую из собранных в разных домах лоскутков (на счастье) [8, с. 50]. Монисто в форме замка-амулета, также известное как замок долголетия, это вид украшения, висящего на шее ребенка, талисман благословения его долгой жизни. Материал замков либо золото или серебро, либо медь, покрытая серебром, либо серебро, покрытое золотом. Обычно на замке выгравированы такие благоприятные слова, как «Долгих лет жизни», «Мира, богатства и славы». Семья просит копейку у каждой семьи, а затем из этих денег отливают замок, висящий на шее ребенка. Это делается для того, чтобы одолжить счастье и почёт из ста счастливых семей, чтобы сохранить жизнь ребенка.

Носить одежду для ребёнка, сшитую из собранных в разных домах лоскутков, означает то же самое, что носить монисто в форме замка-амулета. Это одежда, сшитая из разных по размеру, красочных полос материи, которую попросили у ста семьей, предназначена для детей, чтобы они не заболели. Так называемая сотня семей означает много семей. В представлениях народа, сто - это целое число с наибольшим благоприятным значением.

В настоящее время уровень медицинской помощи значительно улучшился, но ритуал сотого дня, наполненный любовью и добрыми пожеланиями, по-прежнему заслуживает того, чтобы его сохранили. В современном обществе для детей, чтобы отпраздновать 100 дней в соответствии с древними обычаями носят монисто в форме замка-амулета, но из-за повышения уровня жизни людей, оно не отлито из медных денег, которые просят родители, а покупается готовым изделием в магазине, есть очень много стилей замков для людей, чтобы выбрать подходящий. По сравнению со старой одеждой для ребёнка, сшитой из собранных в разных домах лоскутков, родители сейчас склонны покупать новую одежду для своих детей, потому что современные люди больше внимания уделяют гигиене и здоровью, как правило, они думают, что старая одежда несет бактерии, поэтому дети не носят старую одежду, чтобы не болеть.

\section{Ритуал исполнившегося года}

Ритуал исполнившегося года относительно уникален, это одновременно краткое изложение ритуала рождения и начало серии дней рождения, поэтому ритуал исполнившегося года торжественный праздник. Самый важный элемент ритуала - ребенок должен схватить один предмет из предложенных (для определения его склонностей и будущей деятельности). Родители в возрасте одного года показывают ребенку различные игрушки, бытовые товары и принадлежности для разных профессий, чтобы он мог ползти и схватывать предмет, чтобы предсказать жизненный характер, интересы и устремления ребенка.

В произведении «东京梦华录》 («Записи прекрасных снов о Восточной столице») записано: «至来岁生日谓 之周日卒。罗列盘戞于地, 盛果木饮食, 官诰笔研算秤 等, 经卷针线, 应用之物, 观其所先拈者为徵兆, 谓之 
试日卒, 此小儿之盛礼也» [10, с. 225]. что означает: «B день рождения первого года ребенка, родители раскладывают перед ним разные предметы, например: еду, кисть и тушь, счёты, весы, игла и нитка и другие предметы быта, и позволяют ребенку выбирать один из них по своему вкусу, чтобы по схваченным им вещам определить его наклонности и предсказать его судьбу. Это величайший ритуал для ребенка».

Испытание годовалого ребёнка было популярно по всей стране, однако, из-за различных этнических групп и географических различий, предметы, поставляемые родителями, различны. В регионе центральной равнины обычно размещают кисть и тушь, счеты, линейку, печать и т.д. В районах меньшинств обычно размещают книгу, кисть, лук и стрелы и т.д. В традиционной китайской концепции, мужчины должны питать пристрастие к военному делу и ценить просвещение, поэтому родители раскладывают лук и стрелы, кисть и тушь. А женщины должны управлять домашним хозяйством, в совершенстве владеть рукоделием (шитье, вышивание, ткачество), таким образом родители раскладывают иголку и нитку, счеты и ножницы. Общепринятые предметы и для мальчиков, и для девочек - это еда, сокровища, одежда, игрушки.

Кроме этого, еще есть важный обычай в ритуале исполнившегося года - признать названое родство. То есть младенец признает других людей как названных родственников. Причины для того, чтобы признать названое родство различны: судьба, благодарность за благодеяние, чтобы отвести несчастье, укрепить дружбу между родителями. В древности, из-за бедности и отсталых медицинских условий, дети умирали чаще, простые люди верили в судьбу, в счастье и несчастье гороскопа по дню рождения, боялись, что у детей может быть плохая судьба, они считали, что должны признать других людей как названных родственников, чтобы покончить со злом роком. Если ребенок слабый и болезненный с детства, родители выбирали семью с большим количеством детей в качестве названого родства.

В современном обществе, как и в древности, самый важный ритуал - схватить один предмет из предложенных. Но теперь родители показывают детям другие предметы. По мере того, как общество развивается, положение женщин улучшается, разделение труда мужчин и женщин в древнем обществе - мужчины пашут, а женщины ткут (обр. о разделении мужского и женского труда) - радикально изменилось и заменено идеей равенства между мужчинами и женщинами. Поэтому больше нет различий между мальчиками и девочками в предметах. В наши дни родители перед детьми раскладывают: словарь, означающий, что в будущем ребенок станет литератором или ученым, обладающим знаниями. Книги, ручки означают, что дитя станет каллиграфом, сделает гражданскую работу. Мерная линейка означает, что ребенок станет юристом, судьей. Счётный прибор и счеты означают, что он станет торговцем или бизнесменом. Деньги означают, что позже он станет богатым человеком. Печать означает чиновничье место или власть. Живопись, цветная ручка означает, что он станет художником, работником искусства. Клубок шерсти, ткань означает, что он станет дизайнером одежды. Инструмент указывает, что позже он станет музыкантом и т.д.

В настоящее время сознания люди феодальные принципы постепенно ослабевают. Редко бывает, что дети могут быть в безопасности и здоровы с помощью метода признания родства. Если ребенок слабый и болезненный, то родители больше склоняются к посещению больницы, не надеясь на феодальные суеверия. Однако это вовсе не означает, что в современном обществе такое поведение полностью исчезает - признание родства существует, но цель его иная. Как правило, если отношения между двумя семьями очень хорошие, то они хотят, чтобы их дружба продолжалась в следующем поколении, принимая некровное родство. Такая ситуация очень распространена в современном обществе.

Сравнивая целый ряд традиционных и современных ритуалов и обычаев продолжения рода (рождения), не трудно обнаружить то, что, во-первых, со временем религиозный облик ритуала рождения постепенно менялся в сторону упрощения и секуляризации. Во-вторых, традиционные ритуалы и обычаи рождения пронизывают многие феодальные идеи, однако эта идеология была вызвана определенным этапом в развитии общества. В современном обществе ритуалы и обычаи продолжения рода как можно больше уходят от части традиционных ритуалов и обычаев рождения, утративших актуальность в связи с изменившимися культурно-историческими условиями. В-третьих, в традиционных ритуалах и обычаях есть много специфических черт: омовение новорождённого младенца на третий день рождения, банкет в честь исполнившегося месяца ребенка, захват одного предмета из предложенных и т.д. В настоящее время, некоторые традиционные обычаи сохраняются, другие исчезают. Так, омовение новорождённого младенца на третий день рождения постепенно исчезло, исследователи должны восстановить эту часть традиционной культуры, чтобы она сохранилась в памяти.

В-четвертых, современные ритуалы и обычаи рождения в значительной степени являются наследием и новшеством традиционных, которые в связи с прогрессом добавляют новое в содержание и форму. В-пятых, современные ритуалы и обычаи рождения в значительной степени зависят от западной культуры, что указывает на то, что традиционная китайская культура совмещает в себе разные элементы. В-шестых, как традиционные, так и современные ритуалы и обычаи рождения свидетель- 
ствуют о любви и надежде родителей на благополучие новорожденного. Это общая цель всех ритуалов и обы- чаев продолжения рода, независимо от формы и содержания как в древности, так и сейчас.

\section{ЛИТЕРАТУРА}

1. 宋轶兰. 浅议传统人生礼仪 // 阴山学刊. 2003. № 6. 70-72页. = Сун Илан. Обзорный разбор традиционного жизненного ритуала // Академический журнал Иньшань. 2003. № 6. С. 70-72.

2. 刘紫祺. “韩萱”偶尔有人应:萱草的作用 // 陕西科技报. 2017年4月28日，第003版， 1-2页. = Лю Цзыци. 'Хань Сюань' иногда кто-то отвечает: роль Красоднев (лилейник) рыжий // Шэньсиская научно-техническая газета. 28 апреля 2017. № 3. С. 1-2.

3. 陈凡. 诞生礼的古今对比研究 // 青年文学家. 2016. № 15. 174-175页. = Чэнь Фань. Сопоставительное исследование по обряду рождения в древности и ныне. // Молодой литератор. 2016. № 15. С.174-175.

4. 刘亦山. 俗礼新编(内部资料). 1994年. 第79页. = Лю Ишань, Новый сборник народных обычаев (внутренние данные), 1994. С. 79.

5. 刘向. 古列女传 - 母仪篇. 上海: 中华书局, 1936年. 296页. = Лю Сян. Древние жизнеописания знаменитых женщин • Часть образца материнства. Шанхай: Китайское книгоиздательство, 1936. 296 с.

6. 刘红梅, 刘楚鬼斗. 梅山祈子习俗研究 // 求索. 2006. № 4. 63-65页. = Лю Хунмэй, Лю Чукуй. Изучение обычаев моления 0 ниспослании сына в районе Мэйшань. // Поиск. 2006. № 4. С. 63-65.

7. 尉迟从泰. 中原传统社会中汉族的生育禁忌 //商 丘 师 范 学 院 学 报. 2017. № 1.50-58页.= Юй Чи Цун Тай. Табу на рождение ханцев в традиционных обществах Центральной равнины. // Вестник педагогического института Шанцю. 2017. № 1. С. 50-58.

8. 王衍军. 中国民俗文化. 广州: 暨南大学出版社, 2011年. 354页. = Ван Яньцзюнь. Китайская фольклорная культура. Гуанчжоу: Издательство университета Цзинань, 2011.354 с.

9. 尹占华. 王建诗集校注. 成都: 巴蜀书社, 2006年. 668页. = Инь Чжаньху. Сборник стихов Ван Цзянь с комментариями. Чэнду: книгоиздательство башу, 2006.668 с.

10. 孟元老. 东京梦华录. 哈尔滨: 北方文艺出版社, 2019年. 470页. = Мэн Юаньлао. Записи прекрасных снов о Восточной столице. Харбин: литературное издательство север, 2019.470 c.

11. 牛林豪. 摇篮边的祝福 - 诞生礼趣谈 // 中州统战. 2002. № 6. 42-44页. = Ню Линьхао. Благословение на краю колыбели - меткое подобранное выражение о ритуале рождения. // Единый фронт центральная равнина. 2002. № 6. С.42-44.

12. 张国庆. 古代东北各民族“诞生礼”俗探论 // 黑龙江民族从刊. 1997. № 4. 98-101页. = Чжан Гоцин. Изучение ритуалов рождения народов древнего северо-востока // Национальные труды Хэйлунцзян. 1997. № 4. С.98-101.

(c) Ван Дань (wangdan1990112@163.com).

Журнал «Современная наука: актуальные проблемы теории и практики»

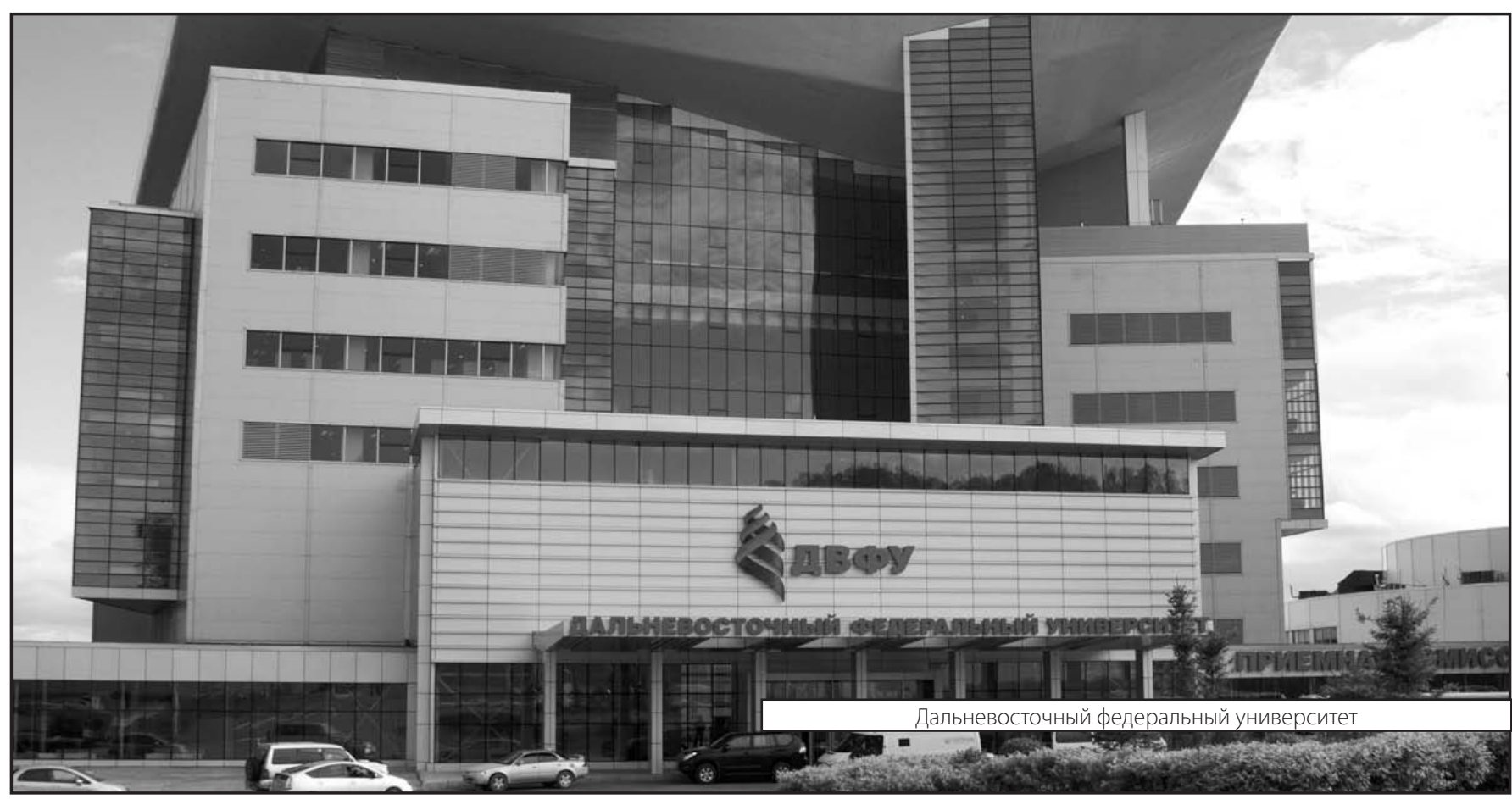

